\title{
STABILITY ANALYSIS AND ESTIMATION SOME GENETIC PARAAMETERS FOR GRAIN YIELD AND ITS COMPONENTS FOR SOME DURUM WHEAT GENOTYPES.
}

\author{
M. A. Hussain \\ Prof.
}

Dept.Field Crops, Coll. Agric. Eng. Sci.
S. Y. Hassan
Researcher

University of Duhok mohemmed.albarwari@yahoo.com

\begin{abstract}
Four durum wheat genotypes exotic from ICARDA and local variety were sown in agricultural season of 20152016, 2016-2017, and 2017-2018, using Randomized Complete Block Design (RCBD) with three replications. The result of the combined analysis of variance exhibited that the mean square of environments, genotypes and to evaluate their stability for genotypes $x$ environment interaction ( $G X X$ ) were significant for all traits, suggesting differential response of genotypes due to environment. When by partitioning $\mathbf{G} X \mathbf{E}$ interaction in to the linear and non-linear (pooled deviation) components, that differences between environments (environment linear) were highly significant for all traits. For the GXE interaction linear, the results indicated that all traits were not significant except 1000-grain weight, The result also indicated that the durum wheat genotypes produced homogeneity for the most studied traits and much variation was noted in plant height and days to maturity. The genotype Miki-3 was superior in hectoliter and plant height and grain yield which gave $84.88 \mathrm{kgL} / 100087$ and $2.37 \mathrm{~T} / \mathrm{ha}$ respectively. The results exhibited that the phenotypic variation was more than the genotypic variation indicating that, the characters more affected by environments. For heritability in broad sense, the results showed moderate value for plant height and days to flowering and low for the rest traits. The genetic advance as the mean was low for all traits with the values ranged between 1.20 to 7.52 for hectoliter and 1000 -grain weight. The lowest differences in genotypic and phenotypic coefficient of variability in the three seasons, this indicated that large amount of variation was contributed by environmental influence and low by genetic components. For stability analysis, the results indicated that the genotypes Miki3 and Simeto gave the best stability according to all parameters of stability with other genotypes and these genotypes gave highest value of grain yield 2.37 and 2.18.
\end{abstract}

Key word: yield, stability, multi seasons, genotypes $\mathrm{x}$ environment, durum wheat.

حسين واًخرون

مجلة العلوم الزراعية العراقية -90-84:53: 2022 (1)

الاستقراية الوراثية و تقدير بعض المعالم الوراثية لحاصل و مكوناته في بعض التراكيب الوراثيه من الحنطة الخشنة.
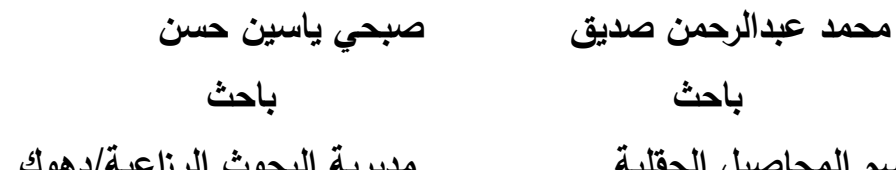

المستخلص

زرعت اربعة تراكيب وراثية من الحنطة الخشنة مدخلة من ايكاردا مع صنف محلي. في موسم الثتوية 2015-2016 , 2016-2017, و 20172018 بأستخدام تصميم القطاعات العشوئية الكاملة و بثلاثة مكررات. أظهر التحليل المشترك تأثيرات معنوية للبيئة و التراكيب الوراثية و التداخل بينهما على جميع الصفات و هذا يعني وجود استجابة مختلفة للتراكيب الوراثية للبيئات لمختلفة و عند التداخل الوراثي البيئي و للعلاقة الخطية و غير واتير

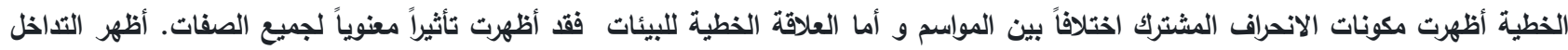
الخطي تأثيراً غير معنوياً لجميع الصفات باستثناء وزن الاندرنئ 1000 بذرة و ان جميع التراكيب الوراثية أظهرت تجانسا لمعظم الصفات المدروسة مع ملاحظة ظهور تباين عالي لارتفاع النبات و عدد الايام للنضج و تفوق التركيب الوراثي (Miki3) في الوزن الحجمي و ارتفاع النبات و حاصل البذور والذي

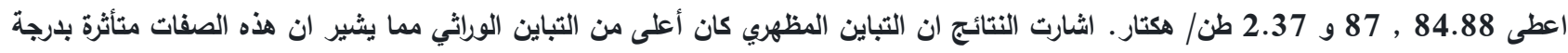
عالية بالظروف البيئية. و كانت قيمة التوريث بالمعنى الواسع متوسطة لارتفاع النبات و عدد الايام الى التزهير واطئة للبقية الصفات و كان التحصيل

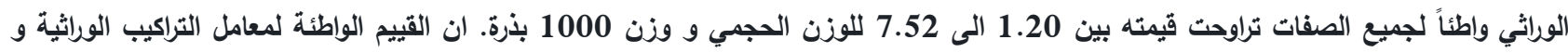
المظهرية في المواسم الثلاثة يدل على وجود تأثيرات بيئية عالية بالمقارنة مع التأثيرات الوراثية. اما تنائج تحليل الاستقرارية الوراثية فقد أظهرت ان

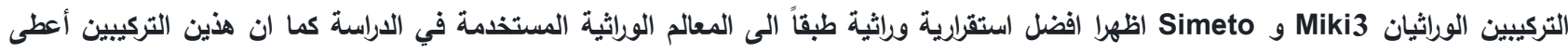
اعلى معامل للبذور 2.37 و 2.18 طن/هكتار كمعل لثثلاث مواسم. الكلمات المفتاحية:الحاصل،الاستقرارية،مواسم متعددة، تداخل وراثي بيئي، حنطة خشنة. 


\section{INTRUDUCTION}

Durum wheat is the most important cereal crops in the world, which was better adapted to semi- arid conditions. karimizaden(14) reported that the durum wheat is grow on $10 \%$ at. World area, it used in different industries such as (bulgar, macaroni and cake and nearly 40 to 50 million tons are produced every year worldwide. Several breeders, all over the world, are attempt through wheat breeding program to develop productive and adapted genotypes to their specific environments. Baran (3) and Evans(9) indicated that yield stability has been described as yield consistency a cross year, while adaption references to the ability of genotypes to perform well across environment. This can be achieved by developing high yielding genotypes, application of improved agrotechniques and cultivating durum wheat in newly reclaimed soil. Also Mustatea(18) refer, that the important to mention that the successful of new genotypes mast show high Performance for yield and yield components, but beside that breeding for yield stability for a wide range of different environmental conditions. Yan(23) indicated that two major problem in assessing cultivars, the first is the negative GE interaction and second deals with basic traits. There for several researchers have been working with durum wheat in different years and environment and explain that the GXE interaction studies are most imported as interaction play significant role in the expression of the performance of different genotypes in different environments, these some studied have been conducted to estimate stability of durum wheat genotypes under different environment. (20)(2)(6) (16) (5)(15) and (17). Several statistical methods have been used for stability investigation, with a few explaining the information comprised in the (GE1) data matrix and the most methods the widely used are (bi) the regression coefficient (10) Sdi, deviation from regression line intercept. The stability of genotypes defined by high mean yield and regression coefficient $\left(b^{1}=1.0\right)$ at deviation from regression $(\mathrm{Sdi}=0)$ as well as possible. The objective of this study were to revaluate the stability and some genetic parameters for yield and its components for four promising durum wheat genotypes.

\section{MATERIALS AND METHODS}

Four durum wheat genotypes and one local variety were used in this study. (1- Smeto, 2Miki3, 3- Icarasha2, 4- Secondroue ,5Berghouata) to evaluate the stability and some genetic parameters in durum wheat. This experiment was carried out using Randomized Complete Block Design with three replications at Research Station of Duhok Center under rain fail Table 1, during agricultural season of 2015-2016, 2016-2017 and 2017-2018. Each experimental unit consisted of a five rows, $5 \mathrm{~m}$ length with $0.3 \mathrm{~m}$ between rows. Seeding rate was $120 \mathrm{kgha}^{-1}$, dap fertilizer was used before sowing date at rate $100 \mathrm{kgha}^{-1}\left(46 \mathrm{P}_{2} \mathrm{O}_{5} \%\right.$ and $18 \% \mathrm{~N}$ ) and urea $46 \% \mathrm{~N}$ was applied at tillering with average $80 \mathrm{kgha}^{-1}$ Data were recorded on ten randomly plants taken for plant height, 1000-grain weight, Hectoliter, days to flowering, maturity and grain yield. A combined analysis of variance genotypes traits data across years was performed according to the method of the experimental design used. Ten differences between the means of the genotypes and three years were compared by Duncans multiple range test.The stability parameters estimated using Eberhart and Russel(7).

Table 1. Amount of rainfall $(\mathrm{mm})$ during the growing season 2015-2018

\begin{tabular}{|c|c|c|c|c|}
\hline & Years & & & \\
\hline Months & 2015 & 2016 & 2017 & 2018 \\
\hline January & 79.4 & 144 & $\begin{array}{l}58.3 \\
\end{array}$ & 76 \\
\hline February & 62.6 & 65.7 & 20.4 & 121.5 \\
\hline March & 71.4 & 104.1 & 102.9 & 19.3 \\
\hline April & 40.2 & 58.6 & 70.1 & 121.9 \\
\hline May & 9.6 & 3.8 & 33.4 & 120.6 \\
\hline June & 0.0 & 1.6 & 0.0 & 1.1 \\
\hline September & 12.2 & 0.0 & 0.0 & 0.0 \\
\hline October & 38.2 & $8 . .8$ & 4.7 & 66. \\
\hline November & 80.1 & 22.6 & 33.7 & 181.1 \\
\hline December & 107.1 & 101.9 & 21.9 & 245 \\
\hline
\end{tabular}




\section{RESULTS AND DISCUSSION}

The combined analysis of variance for five durum wheat genotypes evaluated under three differential years were present in Table 2. The mean squares for varieties and years was significant at $1 \%$ probability level for all studied traits except for grain yield and days to maturity. The mean square of the linear component of genotypes $\mathrm{X}$ environments interaction when tested pooled deviation were not significant for all studied traits except for 1000 -grain weight. This is in line with findings of (11), (12) and (21).

Table . 2. Combined variance and analysis of genotypes at three years

\begin{tabular}{|cccccccc|}
\hline Sov & df. & $\begin{array}{c}\text { 1000-seed } \\
\text { weight }\end{array}$ & $\begin{array}{c}\text { Hector } \\
\text { Letter kg/ } \\
\text { 100 Lt }\end{array}$ & $\begin{array}{c}\text { Plant } \\
\text { height cm }\end{array}$ & $\begin{array}{c}\text { Grain } \\
\text { yield } \\
\text { (g) }\end{array}$ & $\begin{array}{c}\text { Days to } \\
\text { flowering }\end{array}$ & $\begin{array}{c}\text { Days to } \\
\text { maturity }\end{array}$ \\
\hline Variety & $\mathbf{4}$ & $* * 16.29$ & $* * 3.48$ & $* * 34.04$ & $\mathbf{0 . 0 9}$ & $* * 15.41$ & 4.39 \\
E x(v x E) & $\mathbf{1 0}$ & $* * 128.15$ & $* * 10.04$ & $* * 103.33$ & $* * 0.98$ & $* * 159.88$ & $* * 668.92$ \\
E(linear) & $\mathbf{1}$ & $* * 1251.82$ & $* * 93.55$ & $* * 979.30$ & $\mathbf{9 . 4 1 *}$ & $* * 1593.84$ & $* * 6664.56$ \\
V X E(linear) & $\mathbf{4}$ & $* 3.37$ & $\mathbf{0 . 1 6}$ & $\mathbf{4 . 6 9}$ & $\mathbf{0 . 0 5}$ & $\mathbf{0 . 2 0}$ & $\mathbf{2 . 7 4}$ \\
Pooled deviations & $\mathbf{5}$ & $\mathbf{3 . 2 5}$ & $\mathbf{0 . 8 9}$ & $\mathbf{7 . 0 4}$ & $\mathbf{0 . 0 4}$ & $\mathbf{0 . 7 9}$ & $\mathbf{2 . 7 4}$ \\
Pooled error & $\mathbf{3 0}$ & $\mathbf{1 . 1 9}$ & $\mathbf{0 . 1 9}$ & $\mathbf{2 . 3 5}$ & $\mathbf{0 . 0 2}$ & $\mathbf{0 . 4 7}$ & $\mathbf{0 . 2 3}$ \\
\hline
\end{tabular}

*and** significant at 0.05 and 0.1 probability lever respectively

Substantial difference in study traits were found among three environment characterized by different climatic conditions (Table3). For 1000 seed weight varied among environments, the $\mathrm{E}_{1}$ gave the maximum value $(32.98 \mathrm{~g})$, while the $\mathrm{E}_{2}$ had the minimum value $53.98 \mathrm{~g}$ with C.V\% 4.21. Hectoliter obtained highest value 85.54 and lowest value (79.71) was recorded by E1 and Also, The results in Table 3 exhibited that the environment one was superior for grain yield (2-98 T/ha), days to flowering (121-93) and maturity 170.06,

whilst the environment 2 gave the lowest value for grain yield (1.06) and the earliest days to flowering were(100.06). For plant height, the environment 2 recorded the longest plant height $93.13 \mathrm{~cm}$ and the environment 3 gave the shortest plant height $(74.66 \mathrm{~cm})$. From the results in table below the environment one was superior in the most studied traits, the major difference in the most traits were associated to rainfall levels and temperature values, these climatic features influenced the environment mean on grain yield and other evaluated traits, similar finding were recorded by (11) and(13).

Table 3. Yield and some traits performance of five durum wheat genotypes at different environments

\begin{tabular}{|c|c|c|c|c|c|c|}
\hline Env. & $\begin{array}{c}\text { 1000-seed weight } \\
\text { g }\end{array}$ & $\begin{array}{l}\text { Characters } \\
\text { Hector Letter } \\
\text { kg/ 100 Lt }\end{array}$ & $\begin{array}{c}\text { Plant } \\
\text { height } \mathrm{cm}\end{array}$ & $\begin{array}{c}\text { Grain } \\
\text { yield } \\
\text { T/ha }\end{array}$ & $\begin{array}{l}\text { Days to } \\
\text { flowering }\end{array}$ & $\begin{array}{c}\text { Days to } \\
\text { maturity }\end{array}$ \\
\hline E1 & $\begin{array}{c}53.98 \\
\mathbf{a}\end{array}$ & 85.54 a & 90.06 b & $2.98 \quad a$ & $\begin{array}{c}121.93 \\
\text { a }\end{array}$ & $\begin{array}{c}170.06 \\
a\end{array}$ \\
\hline E2 & $\begin{array}{c}32.40 \\
\text { c }\end{array}$ & $\begin{array}{c}79.71 \\
\mathrm{C}\end{array}$ & 93.13 a & $1.06 \mathrm{c}$ & $\begin{array}{c}100.06 \\
b\end{array}$ & $\begin{array}{c}139.60 \\
b\end{array}$ \\
\hline E3 & 48.29 b & 84.24 b & $\begin{array}{c}74.66 \\
\text { C }\end{array}$ & $2.24 \quad b$ & $\begin{array}{c}100.06 \\
b\end{array}$ & $\begin{array}{c}118.73 \\
\text { c }\end{array}$ \\
\hline Mean & 44.89 & 83.16 & 85.95 & 2.09 & 107.35 & 142.79 \\
\hline C.V\% & 4.21 & 0.19 & 3.09 & 13.07 & 1.11 & 0.59 \\
\hline
\end{tabular}

Analysis of variance for five durum wheat genotypes for yield and some traits growing over three environments are given Table 4. All genotypes had significant effect for 1000 grain yield and Hectoliter, whiles the other characters were non significant. The genotypes 3 and genotypes 5 produced highly significant effect for plant height, days to maturity and Hectoliter, while the other genotypes were non significant on all studied traits. The results in the same table, indicated that the durum wheat genotypes produced homogeneity for the most investigated traits and much variation was noted in plant height and days to maturity among all five genotypes. These results are in harmony with those found by (23),(17)and (16). 
Table 4. Analysis of variance for five durum wheat on yield and some traits growing in three environments.

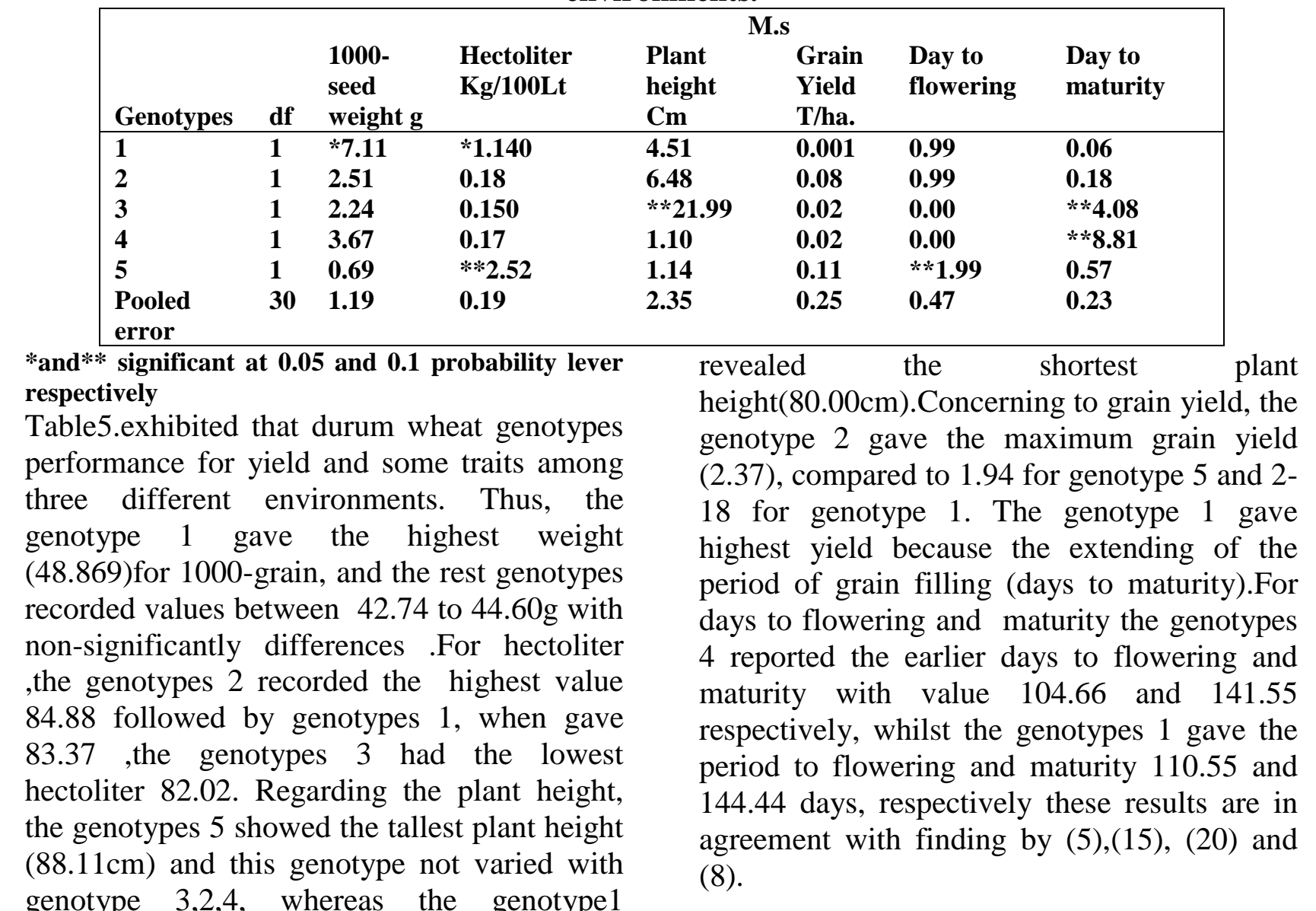

Table5. Genotypes performance for yield and some traits at three different environments

\begin{tabular}{|c|c|c|c|c|c|c|}
\hline Genotypes & $\begin{array}{l}\text { 1000-seed } \\
\text { weight g }\end{array}$ & $\begin{array}{l}\text { Hectoliter } \\
\text { kg } 100\end{array}$ & $\begin{array}{c}\text { Plant } \\
\text { height } \mathrm{cm}\end{array}$ & $\begin{array}{l}\text { Grain } \\
\text { yield } \\
\text { T/ha }\end{array}$ & $\begin{array}{c}\text { Days to } \\
\text { flowering }\end{array}$ & $\begin{array}{l}\text { Days to } \\
\text { maturity }\end{array}$ \\
\hline 1 & 48.86 a & 83.37 b & 80.00 b & $2.18 \mathrm{ab}$ & 110.55 a & 144.44 a \\
\hline 2 & $43.97 \mathrm{~b}$ & 84.88 a & 87.00 a & $2.37 \mathrm{a}$ & $108.44 \mathrm{~b}$ & $142.00 \mathrm{~b}$ \\
\hline 3 & $44.28 \mathrm{~b}$ & 82.02 c & 87.77 a & $1.98 \mathrm{~b}$ & $107.11 \mathrm{c}$ & $142.33 \mathrm{~b}$ \\
\hline 4 & $44.60 \mathrm{~b}$ & 82.74 bc & 86.88 a & $2.00 \mathrm{~b}$ & $104.66 \mathrm{~d}$ & $141.55 \mathrm{~b}$ \\
\hline 5 & $42.74 \mathrm{~b}$ & 82.78 bc & 88.11 a & $1.94 \mathrm{~b}$ & $106.0 \mathrm{c}$ & 143.66 a \\
\hline
\end{tabular}

Statistical analysis for some genetic plant height and days to flowering and low for parameters for yield and some traits in five the rest traits and ranged between 0.08 to durum wheat genotypes over three 0.042.The genetic advance as the mean was environments were presented in Table6. This low for all traits 1.20 to 7.52 for hectoliter and study indicated that the phenotypic variation was more than the genotypes variation for all studied traits. The variation for genotype was high for plant height and low for the rest characters .The genotypic of coefficient were low for all traits, while the phenotypic coefficient was moderate for 1000-grain weight and grain yield and low for the others traits .For heritability broad sense, the results in the same table exhibited moderate value for 1000 -grain yield. The results above, showed lowest differences in genotypic and phenotypic coefficient of variability in the three environments, which indicant that large amount of variation was contributed by environmental influence and low by genetic components and non-additive gene effect indicates that genotypes can be improved hybridization method. Similar result have been recorded by (11),(22) and (21). 
Table 6. Some genetic parameters for yield and some traits in five durum wheat genotypes

\begin{tabular}{|c|c|c|c|c|c|c|}
\hline Parameters & $\begin{array}{l}\text { 1000-seed } \\
\text { weight g }\end{array}$ & $\begin{array}{l}\text { Hectoliter } \\
\text { kg } 100\end{array}$ & $\begin{array}{l}\text { Plant } \\
\text { height } \mathrm{cm}\end{array}$ & $\begin{array}{l}\text { Grain yield } \\
\text { T/ha }\end{array}$ & $\begin{array}{l}\text { Days to } \\
\text { flowering }\end{array}$ & $\begin{array}{l}\text { Days to } \\
\text { maturity }\end{array}$ \\
\hline Vg & 8.50 & 1.43 & 28.82 & 0.01 & 7.71 & 4.29 \\
\hline Vgc & 0.25 & 4.14 & 10.66 & 0.066 & 3.96 & 5.24 \\
\hline Ve & 18.77 & 1.26 & 7.35 & 0.07 & 1.03 & 0.67 \\
\hline Vp & 27.54 & 6.85 & 44.84 & 0.15 & 12.70 & 10.21 \\
\hline $\begin{array}{l}\text { Heritability } \\
\text { broad sense }\end{array}$ & 0.30 & 0.20 & 0.59 & 0.08 & 0.60 & 0.42 \\
\hline GA & 2.85 & 0.96 & 7.05 & 0.05 & 3.80 & 2.38 \\
\hline GAY & 7.52 & 1.20 & 8.00 & 2.66 & 3.81 & 1.64 \\
\hline GCV & 7.69 & 1.49 & 5.92 & 5.31 & 2.78 & 1.43 \\
\hline PCV & 13.83 & 3.25 & 7.65 & 18.67 & 3.57 & 2.21 \\
\hline
\end{tabular}

The stability parameters for yield and some characters in all five durum wheat genotypes over three different environments were presented in Table7. Grain weight the bi for the five genotypes tested was 0.88 for genotype 5 and 1.16 and sdi was not significant indicating that these genotypes has a good response to unsuitable environment. For trait hectoliter the bi for genotype 20.89 and 1.14 for genotype 4 and sdi was not significant so that, these mean that genotypes has a good response for different environments for this trait, whilst the genotypes 5 has (sdi) more than one (high deviation from regression) indicating that this genotypes was not stable for all environments. Concerning to plant height the value bi was close to one and sdi more than one for genotypes 1,2,3 and significant for genotypes 3 and can be considered to be not stable under varying environments since it showed significant deviation from regression. For grain yield Table 7, the results demostrated that the genotypes 2 and 1 had a best stability according to all parameters compared with other genotypes and these genotypes had highest value of grain yield 2.37 and 2.18 was means they respond to good environment because the regression coefficient more than unity and deviation (sdi) not significant from zero. Further more, the days to flowering, it has unity and sdi was not significant indicating that the five durum wheat genotypes has a good response to unsuitable environments, trait days to maturity, also showed that genotypes 3 and 4 had regression coefficient less than one and sdi was significant indicating these genotypes more stable under varying environments. Similar result have been reported by (11) (19) (22)and (12) Goldring, it is worthy to noting the importance of deviation value for mean of each genotypes as a basis for recommendation it. The linear regression of the average of any of the six traits of the single genotype over the average of all genotypes in each environment resulted in regression coefficient values ranging between 0.88 to 1.16 for 1000 -seed weight, 0.89 to 1.14 for hectoliter, 0.79 to 1.14 for plant height, 0.71 to 1.14 for grain yield, 0.91 to 1.07 for days to flowering, 0.92 to 1.62 for days to maturity. These large variation in the regression coefficients, especially for hectoliter, days to maturity and days to flowering indicate the different response genotypes to environment changes (Table 7).

Table 7.Stabiity parameter for yield and some character in five durum wheat genotypes

\begin{tabular}{|c|c|c|c|c|c|c|c|c|c|}
\hline \multirow[t]{2}{*}{ Genotypes } & \multicolumn{3}{|c|}{ 1000-seed weight $(\mathrm{g})$} & \multicolumn{3}{|c|}{ Hectoliter } & \multicolumn{3}{|c|}{ Plant height (cm) } \\
\hline & $\mathbf{B i}$ & $S^{2} d i$ & $\dot{\mathbf{x}}$ & bi & $S^{2} d i$ & $\dot{\mathbf{x}}$ & bi & $S^{2}$ di & $\dot{\mathbf{x}}$ \\
\hline 1 & 0.90 & 5.87 & 48.86 & 1.12 & 1.11 & 83.37 & 0.88 & 2.28 & 80.00 \\
\hline 2 & 0.98 & 1.27 & 43.97 & 0.89 & -0.10 & 84.88 & 0.79 & 4.23 & 87.00 \\
\hline 3 & 1.06 & 1.00 & 44.28 & 1.04 & -0.13 & 82.02 & 1.04 & $* * 19.74$ & 87.77 \\
\hline 4 & 1.16 & -2.43 & 44.60 & 1.14 & -0.10 & 82.74 & 1.12 & 1.15 & 86.88 \\
\hline 5 & 0.88 & -0.54 & 42.74 & 0.99 & 2.24 & 82.78 & 1.14 & -1.10 & 88.11 \\
\hline
\end{tabular}

\begin{tabular}{|lllllllll|}
\hline \multicolumn{2}{|l}{ Grain yield $(\mathrm{g})$} & & \multicolumn{3}{c}{ Days to flowering } & \multicolumn{2}{c|}{ Days to maturity } \\
Bi & $\mathbf{S}^{2}$ di & $\dot{\mathbf{x}}$ & bi & $\mathbf{S}^{2}$ di & $\dot{\mathbf{x}}$ & Bi & S di & $\dot{\mathbf{x}}$ \\
\hline $\mathbf{0 , 9 5}$ & $\mathbf{- 0 . 0 1}$ & $\mathbf{2 , 1 8}$ & $\mathbf{1 , 0 3}$ & $\mathbf{0 , 7 9}$ & $\mathbf{1 1 0 , 5 5}$ & $\mathbf{1 , 6 2}$ & $\mathbf{- 0 . 9 6}$ & $\mathbf{1 4 4 , 4}$ \\
$\mathbf{1 , 1 4}$ & $\mathbf{0 . 0 6}$ & $\mathbf{2 , 3 7}$ & $\mathbf{1 . 0 7}$ & $\mathbf{0 , 7 9}$ & $\mathbf{1 0 8 , 4 4}$ & $\mathbf{1 , 0 4}$ & $\mathbf{- 0 . 8 4}$ & $\mathbf{1 4 2 . 0}$ \\
$\mathbf{1 , 1 3}$ & $\mathbf{0 , 0 1}$ & $\mathbf{1 , 9 8}$ & $\mathbf{1 , 0 2}$ & $\mathbf{- 0 . 2 0}$ & $\mathbf{1 0 7 , 1 1}$ & $\mathbf{0 , 9 2}$ & $* * 3.05$ & $\mathbf{1 4 2 , 3}$ \\
$\mathbf{1 , 0 4}$ & $\mathbf{0 , 0 1}$ & $\mathbf{2 , 0 0}$ & $\mathbf{0 , 9 6}$ & $\mathbf{- 0 . 1 9}$ & $\mathbf{1 0 4 , 6 6}$ & $\mathbf{0 , 9 8}$ & $* * 7.78$ & $\mathbf{1 4 1 , 5}$ \\
$\mathbf{0 , 7 1}$ & $\mathbf{0 , 0 9}$ & $\mathbf{1 , 9 4}$ & $\mathbf{0 , 9 1}$ & $\mathbf{1 , 7 9}$ & $\mathbf{1 0 0 , 0 0}$ & $\mathbf{1 , 0 2}$ & $\mathbf{- 0 . 4 4}$ & $\mathbf{1 4 3 , 6}$ \\
\hline
\end{tabular}




\section{REFERENCES}

1. Acevedo.A and P. Silva, "Trigo Candeal Calidad, Mercado y Zonas de Cultivon in serie ciencias Agronomicas Universidad be chile, " Facultad de siencias gronómicas, Region Metopolitana Chile, , 2007 .view at :Google Schorar

2. AI-otayk.S.M.2010.Performance of yield and stability of wheat genotypes under high stress environments of central Region of saudi Arabia .JKAV: Meterorol environ .Arid Land Agri.sci:21:81_92

3. Baran.B.C,Binswanger.H.P, Rana.B.C, and G.P.Rao.1981.The use of risk a variation in plant breeding .Concept and application.Euphytica.30,451_458

4. Bassi.F.M and M.shanches-garica2017.Adoptation and stability analysis of ICARADA Durum wheat Elites across 18 countries. Crop. Science v 57(5);2419-2430

5. Bayevanos.D.E,Korpetis, E.Irakli.M, and I.T Tsiatas,2017.Evaluation of durum wheat selection scheme under mediterranean conditions adjusting trial Locations and replications .Euphytica.213(4):82

6. Comstock.R.E, and Moll 1963. The measurement and significance of genotypeenvironment interaction. In statistical genetics and plant Breedings .(Eds.W.D Hanson and H. Robinson) NASNRC pub .Washington.Dc-pp. 164-196

7. Eberhart.S.17 and W.A.Russell.1966. Stability parameters for comparing varieties Crop.Sci.6:36-40

8. EI_Ameen.T.2012. Stability analysis of selection wheat genotypes under different environment conditions in upper Egpt.Afr..J.Agric.Res.7:4838_4844

9. Evans.L.I 1983.Crop evolution, adaption and yield. Cambridge University press New York

10. Finlay.W and G.Wilkinson.1963. The analysis of adaptation in a plant breeding program. Aust.J.Agri.Res.14:742-754

11. Gaelle.V.F, Pierre.R, Sophi.P, and B.Raphael.2020. Genetic diversity and stability of performance of wheat population varieties developed by participatory breeding.Sustainability12,;1-21
12. Goldring. $\mathrm{Z}$,Serpolay. E, and A.Gostanzo.2017.Varisties and population for on -farm participatory plant breeding .Divers food innovation Fastsheet 2;35-45

13. Ismail.H.A, and Mohammed.A.H.2014 Genetic Stability in some bread wheat cultivars Jordan.J.Agri.Sci. 10(2) 225-235

14. karimizaden.R, M.Mohammadi, M.Sheikh Mamo, V.Bavi ,T.Hoseinpour, H.Khan Zaden, H.Ghojogh and Marmion.2011. Application of multivariate methods indereminy grain yield stability of durum wheat genotypes in semiwarm dry land areas of Iran .Modern Genet.J.16:33-38

$15 . \quad$ Magallanes-Lopel.A.M, Ammark.K,Morales-Dorantes, A.GonZaleSantoyo, H.Crossa.T, and C.Guzman. 2017. Grain quality traits of commercial durum wheat varieties and their relationships with drought stress and glytenins Composition .J. of Cercal Sci.75-1-9 .

16-Mohamed.S.Hassan,G.I.A.Mohamed and R.A.K-EI-Said 2013. Stability analysis for grain yield and its components of some durum wheat genotypes under difference environment .Asia.J-of Crop Science 5(2)179_189

17. Mohammedi.R, Armion.M, Zadrasan.E, Ahmadi.M.M, and A.Amri. 2018 .The use of AMMI Model for inter pretiny genotype $\mathrm{X}$ environment interaction in durum wheat .Exp.Agri.54(5) 670-683

18. Mustatea.P ,N.N .Saulescu, G.Ittu, G. pauhescu and L.Voinea.2009. Grain yield and yield stability of winter wheat cultivars in contrasting weather conditions Rom.Agric .Res.26:1_8

19. Over K.2019.Comparins durum wheat cultivars by genotype $\mathrm{X}$ yield $\mathrm{X}$ trait and genotype $\mathrm{X}$ trait bi plot method.Chil.J.Agric.Res.79(4)1-16

20. Parveen . L.I.H, Khalil and S.K.Khalil. 2010. Stability parameters for tillers grain weight and yield of wheat cultivars in NorthWest of Pkistan. Pak. J. Bot. 42: 1613-1617

21. Prieto.1, Violle.C, Barre.P, Durand.J.L, Ghesquiere .M and I .Litrico .2015. Complementary effect of species and genetic diversity on productivity and stability of sown grasslands. Nat-Plants 1,:15033-15037 
22. Reiss.E.R, and L.E.Drink water 2018.Cultivar mix true ; A meta-analysis of the effect of intra a specific diversity on crop yield .Ecol.Appi.28;62-78
23. Yan.w, Fregeau_Reid .2018.Genotype by yield X Trait (GKT)Bi plot: anovel Approacn for genotype selection based on multiple traits. Scientific Reports.8:8242. 